\title{
Students' Perception of the Effectiveness of Entrepreneurship Education at a South African University
}

\author{
Olawale Fatoki \\ Department of Business Management, Turfloop campus, University of \\ Limpopo, Limpopo Province, South Africa \\ Email: Olawale.fatoki@ul.ac.za \\ Olabanji Oni \\ Department of Business Management, Turfloop campus, University of \\ Limpopo, Limpopo Province, South Africa \\ Email: Olabanji.oni@ul.ac.za
}

\section{Doi:10.5901/mjss.2014.v5n20p585}

\begin{abstract}
The objective of the study was to investigate the perception of university students that have done entrepreneurship about the effectiveness of entrepreneurship education. The study adopted a quantitative research approach with a descriptive design. The study focused on the final year students (undergraduate level) in the Department of Business Management at a selected University located in the Limpopo Province of South Africa. Data was collected through the use of self-administered questionnaires in a survey. The results suggest that entrepreneurship education is effective with respect to certain outcomes and ineffective in some areas. Entrepreneurship education encourages students to take on entrepreneurship as a career and gives students the skills needed to be entrepreneurial. However, entrepreneurship education does not seem effective in helping students to meet people with good business ideas or preparing students on how to access finance. Recommendations to improve the effectiveness of entrepreneurship education are suggested.
\end{abstract}

Keywords: perception, university students, entrepreneurship education, South Africa

\section{Introduction}

Blenker et al. (2006) point out that entrepreneurship and innovation are high on the political agenda of many countries. Universities are expected to play a central part in a process where the primary objective is to ensure the continuous development of a country through entrepreneurship in order to maintain a secure platform for employment, economic growth and improved welfare. Gerba (2012) observes that fostering entrepreneurship has become a topic of highest priority in public policy. Matlay (2006) notes that entrepreneurship education is believed by policy makers to result in growth in the quantity and quality of entrepreneurial activity. According to Sardeshmukh and Smith-Nelson (2011), there is the need to provide the kind of education that is needed to develop an opportunity-oriented entrepreneurial mind set among tertiary students. In addition, employers want graduates that are entrepreneurially minded. Lourenco et al. (2013) point out that the development of an entrepreneurial mind-set and/or enterprising skills is on the agenda for developing graduates in order to enhance their employability. Employers are looking for graduates equipped with skills that will enable them to act in enterprising ways so they can deal effectively with a difficult business environment, and a personal life that is increasingly full of uncertainties and complexities.

Herrington et al. (2009) note that given the failure of the private and public sectors to absorb the growing number of job seekers in South Africa, increasing attention has focused on entrepreneurship and new firm creation and their potential for contributing to economic growth and job creation. Youth and student entrepreneurship can help to improve the low rate of enterprise creation in South Africa. According to Turton and Herrington (2012), South Africa's Total Entrepreneurial Activity (TEA) rate decreased from 9.1\% in 2011 to $7.3 \%$ in 2012. South Africa's TEA is significantly below the average of efficiency-driven countries (14.3\%). the number of potential entrepreneurs is South Africa is below international standards. Potential entrepreneurs are defined by the Global Entrepreneurship Monitor (GEM) as those who perceive good business opportunities and believe that they have entrepreneurial capabilities. Potential entrepreneurs include students in high schools and universities. South Africa's rate of perceived opportunities is $36 \%$. This is below the 
average for efficiency-driven economies of $41 \%$. The country's rate for perceived capabilities is $40 \%$, below the average for of perceived opportunities efficiency-driven economies of 52\% (Turton and Herrington 2012).

Lourenço and Jones (2006) assert that entrepreneurship education in higher educational institutions is supported in many countries based on the assumption that entrepreneurship skills can be learned. Parallel to the evolution of the field of entrepreneurship is the development of educational programs to encourage and foster entrepreneurship (Alberti et al. (2004). According to Henry et al. (2005) and Solomon (2007), there is a considerable uncertainty in the field of entrepreneurship as to whether entrepreneurs are born or made. This has led to an ongoing debate in the entrepreneurship academy about whether individuals can be taught entrepreneurship. Adcroft et al. (2004) argue that entrepreneurs cannot be manufactured but only recognised. This suggests that entrepreneurship cannot be taught. Drucker (1985) points out that entrepreneurship is a discipline and, like any discipline, it can be learned. Kuratko (2003) points out that the question of whether entrepreneurship can be taught is obsolete. Entrepreneurship can be taught or at least encouraged by entrepreneurship education. Lee et al. (2005) ascertain that entrepreneurship education provides students with the motivation, knowledge, and skills that are essential for launching a successful venture. This suggests that entrepreneurial talents can be "matured-up" by education. Azim and Al-Kahtani (2014) note that while no amount of education can provide business success for those who lack the entrepreneurial spirit, experience shows that people are entering schools and universities to learn about entrepreneurship. There is a growing acceptance that elements of entrepreneurship can be taught and learned.

Lorenco and Jones (2006) point out that there is a consensus in the literature that entrepreneurship can be taught and the debate has now shifted to what and how it should be taught. Current evidence however seems to suggest that there is a gap between the perceived desirability of entrepreneurship amongst students and actual self-employment and start-up rates amongst graduates. This has focused attention on the impact of entrepreneurship education. The nature, relevance and appropriateness of entrepreneurship education have been subject to increasing scrutiny (Lee and Wong 2005). According to Arasti et al. (2012), the key to a successful entrepreneurship education is to find the most effective way to manage the teachable skills and identify the best match between student needs and teaching techniques. Borchers and Park (2010) observe that the primary objective of entrepreneurship education program is to develop leaders with strong skills and an entrepreneurial mind-set. Entrepreneurship education includes a large range of outcomes such as knowledge, skills, and attitudes as well as outcomes that go beyond the classroom. Thus, it is important to measure the effectiveness of entrepreneurship education (Al moosa and Porkodi, 2014). According to Gerba (2012), most of the studies on the effectiveness of entrepreneurship education have focused on the viewpoint of academics, however, it is important to obtain the perception of students.

\section{The Objective of the Study}

The objective of the study is to investigate the perception of university students that have done entrepreneurship about the effectiveness of entrepreneurship education.

\section{Literature Review}

\subsection{Definition of entrepreneurship}

Mokaya et al. (2012) note that the literature has been inconsistent in the definition of entrepreneurship. The many definitions of entrepreneurship are a testimony to its diverse nature. The definitions have emphasised a broad range of activities including the creation of organisations, the carrying out of new combinations, the exploration of opportunities, the bearing of uncertainty and the bringing together of factors of production. Mokaya et al. (2012) define entrepreneurship as "the individual motivation and willingness to take risk, create and sustain a growth-oriented and profit making enterprise". Gedeon (2010) agrees that the term entrepreneurship (or who is an entrepreneur) lacks a single unified and accepted definition. The literature is replete with criteria ranging from creativity and innovation to personal traits such as appearance and style (Fernald et al. 2005). According to Gedeon (2010), Cantillon, Turgot, Say and Schumpeter laid the foundations for the meaning of entrepreneurship. Cantillon defines the entrepreneur as someone who assumes the risk and may legitimately appropriate any profits. Turgot and Say point out that the entrepreneur obtains and organizes production factors to create value. Schumpeter (1934) relates entrepreneurship to innovation. The innovative activity of entrepreneurs feeds a creative "destruction process" by causing constant disturbances to an economic system in equilibrium, creating opportunities for economic rent. In adjusting to equilibrium, other innovations are spun-off and more entrepreneurs enter the economic system. McCleland (1961) asserts that entrepreneurial activity involves risk-taking, 
energetic activity, individual responsibility, money as a measure of results, anticipation of future possibilities, and organizational skills. Drucker (1985) observes that the entrepreneur always searches for change, responds to it, and exploits it as an opportunity. Innovation is the tool of entrepreneurship

\subsection{The meaning of entrepreneurship education}

Garba (2012) asserts that the term "entrepreneurship education" has been defined in several ways in entrepreneurship literature. Shepherd and Douglas (1997) propose that "The essence of entrepreneurship education is the ability to envision and chart a course for a new business venture by combining information from the functional disciplines and from the external environment in the context of the extraordinary uncertainty and ambiguity which faces a new business venture. It manifests itself in creative strategies, innovative tactics, uncanny perception of trends and market mood changes, courageous leadership when the way forward is not obvious and so on. What we teach in our entrepreneurship classes should serve to instil and enhance these abilities".

Laukkannen (2000) distinguishes two areas of entrepreneurship education: (1) Education about entrepreneurship. This includes developing, constructing and studying the theories of entrepreneurship and the entrepreneurial process. (2) Education for entrepreneurship. This addresses present and potential entrepreneurs with the objective of developing and stimulating the entrepreneurial process. It also includes the provision of all the tools necessary for the start-up of a new venture both inside and outside an existing organisation.

Education about entrepreneurship primarily involves the construct and transfer of knowledge about the field of entrepreneurship. Education for entrepreneurship concentrates on the learning experience and the development of entrepreneurial competencies, skills, aptitudes and values.

Alberti et al. (2004) define entrepreneurship education as "the structured formal conveyance of entrepreneurial competencies, which in turn refers to the concepts, skills, and mental awareness used by individuals during the process of starting and developing their growth oriented ventures. Entrepreneurship education aims at building entrepreneurial competencies, which are considered as combinations of the different skills, knowledge and attitudes"

According to Garavan and O'Cinneide (1994), the most commonly cited objectives of entrepreneurship education and training programmes are:

- to acquire knowledge germane to entrepreneurship;

- to acquire skills in the use of techniques, in the analysis of business situations, and in the synthesis of action plans;

- to identify and stimulate entrepreneurial drive, talent and skills;

- to undo the risk-adverse bias of many analytical techniques;

- to develop empathy and support for all unique aspects of entrepreneurship;

- to devise attitudes towards change; and

- to encourage new start-ups and other entrepreneurial ventures.

Henry et al. (2005) point out that the two important objectives of entrepreneurship education programmes are (1) to increase the awareness and understanding of the process involved in initiating and managing a new business, and (2) to increase students' awareness of small business ownership as a serious career option. Frank et al. (2005) agree that entrepreneurship education aims at creating or increasing entrepreneurial attitudes, spirit and culture among individuals and in the general community. Entrepreneurship education is associated with opportunity recognition, venture creation and growth. This is consistent with the view of Klein and Bullock (2006) that entrepreneurship education should include the management of existing resources, the acquisition new resources, the identification of existing opportunities and the creation new opportunities

Souitaris et al. (2007) find that entrepreneurship programs significantly raised students' subjective norms and intentions toward entrepreneurship by inspiring them to choose entrepreneurial careers. Basu and Virick (2008) find that prior exposure to entrepreneurship education has a positive effect on students' attitudes toward a career in entrepreneurship and on perceived behavioural control or entrepreneurial self-efficacy. Raposo and Depaco (2011) point out that entrepreneurial attitudes are not only required in the course of a classic entrepreneurial career, but they are also in high demand independent employment relationships. According to Ismail et al. (2009), entrepreneurial education at tertiary level has also become an essential component of many curriculums in higher learning institutions. Since future entrepreneurs can be found amongst those who are currently undergoing their educational process at the universities, entrepreneurship education has been used as one of the most effective ways to promote the transition of graduates into the world of entrepreneurship. Entrepreneurship education helps in imparting entrepreneurial skills among individuals 
(Mwasalwiba, 2010). Thus entrepreneurship education is highly important to entrepreneurial intention, opportunity recognition and new venture creation. Ediagbonya (2013) asserts that entrepreneurship education is the kind of education given to people with a view to developing entrepreneurship qualities properly followed up with support services for smooth take off and successful running of business. Entrepreneurship education seeks to provide student (especially those in tertiary schools) with the knowledge, skills and motivation to encourage entrepreneurial studies in a variety of setting. Schools for entrepreneurship are an important link between theoretical knowledge and practical involvement in the market. The Consortium of Entrepreneurship Education (2013) observes that entrepreneurship education seeks to prepare people, especially youth, to be responsible, enterprising individuals who become entrepreneurs or entrepreneurial thinkers and who contribute to economic development and sustainable communities. Entrepreneurship education is not only about teaching how to run a business, it is also about encouraging creative thinking and promoting a strong sense of self-worth and accountability. Through entrepreneurship education, students learn how to create a business, but they also learn a lot more. The core knowledge created via entrepreneurship education includes: the ability to recognize opportunities in one's life; the ability to pursue such opportunities by generating new ideas and marshalling needed resources; the ability to create and operate a new venture and the ability to think in a creative and critical manner.

\section{Research Methodology}

The study adopted a quantitative research approach with a descriptive design. The study focused on the final year students (undergraduate level) in the Department of Business Management at a selected University located in the Limpopo Province of South Africa. These are students that have done entrepreneurship. The student population was 249. Raosoft sample size calculator gave a sample size of 152. However, 180 questionnaires were distributed in class to the students with the assistance of the lecturer. Data was collected through the use of self-administered questionnaire in a survey. A sixteen item questionnaire was developed to measure the effectiveness of entrepreneurship education. The questionnaire was adapted from previous studies on the effectiveness of entrepreneurship such as Borchers and Park (2011) and Al moosa and Porkodi (2014). The questions were divided into four main groups to capture the multidimensional outcomes of entrepreneurship education as highlighted by Borchers and Park (2011). The groups are (1) behavioural/attitudinal: This involves behaviours such as being an entrepreneur and participating entrepreneurial activities such as creating a new venture (2) Cognitive: this involves knowledge about the entrepreneurship and business acumen. (3) Affective: This includes motivational outcomes such as self-efficacy, goal level, and goal commitment, and satisfaction for the entrepreneurship education program (4) Skill-based: this includes proficiency to use the entrepreneurship knowledge and business acumen. The questionnaire used the 7 point Likert scale ranging from " 1 strongly disagree" to "7 strongly agree". Reliability was measured using the Cronbach's alpha. The coefficient alpha for the measures of the effectiveness of entrepreneurship education was 0.86 , which indicated a very high reliability. The study used descriptive statistics and the T-test for data analysis.

\section{Results and Discussions}

180 questionnaires were distributed in class and 165 questionnaires were returned. The response rate was 91.7\%. 10 questionnaires were found unusable because of the failure of the respondents to complete vital parts of the questionnaire. 155 questionnaires were found usable. 68 respondents were male and 87 were female.

Table 1: students' perception of the effectiveness of entrepreneurship education

\begin{tabular}{|l|c|c|}
\hline \multicolumn{1}{|c|}{ Entrepreneurship education outcomes } & Mean & Standard deviation \\
\hline Behavioural/attitudinal & & \\
\hline I consider entrepreneurship as a desirable career option. & 5.52 & 0.86 \\
\hline Students are encouraged to pursue entrepreneurship ventures in the university. & 4.01 & 0.91 \\
\hline My university and my lecturers helped me to meet people with good ideas for new ventures. & 3.26 & 0.95 \\
\hline Cognitive & & \\
\hline I consider entrepreneurship class as an ideal place to learn about how to start a business. & 6.05 & 0.86 \\
\hline $\begin{array}{l}\text { My lecturers stimulated interest in entrepreneurship through the subjects on entrepreneurship and small } \\
\text { business management. }\end{array}$ & 6.02 & 0.84 \\
\hline Practical examples of entrepreneurship were included in classroom teaching. & 4.25 & 0.89 \\
\hline Through entrepreneurship lectures, I now understand the importance of entrepreneurship. & 6.20 & 0.92 \\
\hline
\end{tabular}




\begin{tabular}{|l|c|c|}
\hline Affective & & \\
\hline My university's entrepreneurship course prepares students very well for entrepreneurial careers. & 5.45 & 0.86 \\
\hline There are student organisations on the university campus that promote entrepreneurship. & 6.20 & 0.82 \\
\hline A creative environment in the university stimulates me to develop ideas for new ventures. & 3.90 & 1.01 \\
\hline The university provides resources/ support to assist student entrepreneurs. & 3.85 & 0.86 \\
\hline Skill-Based & & \\
\hline $\begin{array}{l}\text { I was able to develop entrepreneurial knowledge, skills and competencies through the entrepreneurship } \\
\text { subjects that that I attended. }\end{array}$ & 5.35 & 1.03 \\
\hline As a result of taking subjects on entrepreneurship, I have better understanding about business. & 5.35 & 1.09 \\
\hline Through entrepreneurship lectures, I have learnt how to prepare a business plan. & 5.98 & 0.82 \\
\hline $\begin{array}{l}\text { Through entrepreneurship lectures, I have learnt to approach banks and financial institutions for financial } \\
\text { support. }\end{array}$ & 4.02 & 0.93 \\
\hline Through entrepreneurship lectures I have learnt how to register a patent and register a business. & 4.10 & 0.96 \\
\hline
\end{tabular}

Table 1 depicts the results of the data analysis of the perception of students about the effectiveness of entrepreneurship education. The T-test (sig 0.05) did not show any significant gender difference in all the outcomes of entrepreneurship education.

Behavioural/attitudinal outcomes: The results indicate that most of the respondents agree that entrepreneurship is a desirable career option. However, the results also suggest that the university students are not encouraged to pursue entrepreneurship ventures in the university and lecturers are not helping students me to meet people with good ideas for new ventures. This can be attributed to the teaching method that is being used to teach entrepreneurship. Ediagbonya (2013) finds that entrepreneurship education seeks to provide student with the knowledge, skills and motivation to encourage entrepreneurial activities. Ismail et al. (2009) point out that future entrepreneurs can be found amongst those who are currently undergoing educational process at the universities. Entrepreneurship education is one of the most effective ways to promote the transition of graduates into the world of entrepreneurship.

Cognitive outcomes: most of the respondents agree that the entrepreneurship class is an ideal place to learn about entrepreneurship and that lecturers have stimulated their interest in entrepreneurship. However, the results also suggest that the use of practical examples in classroom teaching is weak. Mwasalwiba (2010) points out that the two primary teaching methods for entrepreneurship are the traditional (passive) method and the innovative (active) method. The traditional method consists of lectures and the innovative method is more action based. The three most applied teaching methods in entrepreneurship classes are lectures, case studies and group discussions which can be grouped under the traditional method. This traditional method is less effective than the innovative method in influencing entrepreneurial behaviour.

Affective outcomes: Most of the respondents agree that entrepreneurship course prepares students for an entrepreneurship career and that there are student organisations on the university campus that promote entrepreneurship.

Skill outcomes: Most of the respondents agree that they are able to develop entrepreneurial knowledge, skills and competencies through the entrepreneurship subjects that they attended. The subjects have also given the students the ability to prepare business plans. However, the results suggest that students are relatively are weak in the area of approaching commercial banks and other financial institutions for support. According to Phelan and Sharpley (2007), there are certain skills and competencies that are needed for the development of a career in entrepreneurship. entrepreneurial competencies refer to the sum of the entrepreneur's requisite attributes for successful and sustainable entrepreneurship. These attributes include attitudes, values, beliefs, knowledge, skills, abilities, personality, wisdom, expertise (social, technical, and managerial), mind-set, and behavioural tendencies. Inyang and Enuoh (2009) find that entrepreneurial competencies are necessary for the development and survival of business ventures.

The results suggest that entrepreneurship education is effective with respect to certain outcomes but also ineffective in some areas. Entrepreneurship education seems to encourage students to take on entrepreneurship as a career and gives students the skills needed such as how to prepare a business plan. However, entrepreneurship education does not seem effective in helping students to meet people with good business ideas or in preparing students on how to access finance.

\section{Conclusions}

Fostering entrepreneurship has become a topic of highest priority in public policy. Universities are expected to play a central part in a process where the primary objective is to ensure the continuous development through entrepreneurship 
in order to maintain a secure platform for employment, economic growth and improved welfare. The objective of the study was to investigate the perception of university students that have done entrepreneurship about the effectiveness of entrepreneurship education. The results suggested that entrepreneurship education is effective with respect to certain outcomes but also ineffective in some areas. Entrepreneurship education encourages students to take on entrepreneurship as a career and gives students the skills needed such as how to prepare a business plan. However, entrepreneurship education does not seem effective in helping students to meet people with good business ideas.

\section{Recommendations}

Business owners should be involved in entrepreneurship education. Business owners should be invited to deliver lectures to students about entrepreneurship. Business owners should also be willing to act as mentors to students. The link between university and business should be enhanced to promote entrepreneurship. Students need to be involved in internship activities with business to gain real practical business experience. The teaching and assessment methods for entrepreneurship should not only focus on traditional (passive) methods but also on innovative (active) methods. Universities should provide support and resources to promote entrepreneurship on the campus. Each university such have an entrepreneurship incubator centre. Government agencies that support entrepreneurship in South Africa such as the Small Enterprise Development Agency (SEDA) and the Small Enterprise Finance Agency (SEFA) should include student entrepreneurship in their strategic framework. These agencies and also commercial banks should also be involved in the teaching of entrepreneurship. SEFA and commercial banks should be involved in teaching students on the kind of business plans that are likely to be successful and how to access finance. Student entrepreneurs in order to improve their entrepreneurial skills and competencies should join student groups that support entrepreneurship on the campus such as Enactus. Entrepreneurship education should be extended to all student entrepreneurs by the universities to improve their competencies.

\section{Limitations}

The study was conducted at only one university. Thus, caution must be exercised in interpreting the findings and in making generalisations. Data collection could be expanded to include a larger sample from other universities in South Africa.

\section{References}

Adcroft, A., Willis, R., Dhaliwal, S. (2004). Missing the point? Management education and entrepreneurship. Management Decision, 42( $3 / 4): 512-521$

Alberti, Fernando, Sciascia, Salvatore, Poli, Alberto (2004), Entrepreneurship Education: Notes on an Ongoing Debate. 14th Annual International Entrepreneurship Conference, University of Napoli Federico II (Italy), 4-7 July 2004

Al moosa, H.A., Porkodi, S (2014). Measuring the effectiveness of entrepreneurial education among HCT students of Oman: A SEM approach. The International Journal of Economics and Business Studies, 3(5): 43-52

Arasti, Z., Falavarjani, M.K., Imanipour, N. (2012). A study of teaching methods in entrepreneurship education for graduate students. Journal of Higher Education Studies, 2(1):2-10.

Azim, M.T., Al-Kahtani, A.H.M (2014). Entrepreneurship Education and Training: A Survey of Literature. Life Science Journal, 11(1): 127135

Basu, Anuradha, Virick, Meghna, (2008), Assessing entrepreneurial intentions amongst students: A comparative study. [Online] Available: http://works.bepress.com/anuradha_basu/12/ (December 15, 2013)

Blenker, Per, Dreisler, Poul, Kjeldsen, John (2006), Entrepreneurship education- the new challenge facing the universities. . [Online] Available: http://pure.au.dk//portal/files/32345606/2006-02_ENG.pdf (June 2, 2014)

Borchers, A., Park, S. (2010). Understanding Entrepreneurial Mindset: A Study of Entrepreneurial Self Efficacy, Locus of Control and Intent to Start a Business. Journal of Engineering Entrepreneurship. 1(1): 51-62

Consortium of Entreprenuership Education (2013). Entrepreneurship Education. [Online] Available: http://www.entre-ed.org/ (February 9, 2013)

Drucker P.F. (1985) Innovation and Entrepreneurship, London: Pan Books Ltd.

Ediagbonya, K. (2013). The roles of entrepreneurship education in ensuring economic empowerment and development. Journal of Business Administration and Education, 4(1): 35-46

Fernald, L.W., Solomon, G.T., Tarabishy A.A. (2005). New paradigm: Entrepreneurial leadership. Southern Business Review, 30(2): 110.

Frank, H., Korunka, C., Lueger, M., \& Mugler, J. (2005). Entrepreneurial orientation and education in Austrian secondary schools. 
Journal of Small Business and Enterprise Development, 12(2), 259-273.

Garavan, T.N., O'cinneide, B. (1994). Entrepreneurship education and training programmes: a review and evaluation. Journal of European Industrial Training, 18 (8), 3-12.

Gedeon, S (2010). What is Entrepreneurship? Entrepreneurship Practice Review, 1(3):16-35

Gerba, D.T. (2012). Impact of entrepreneurship education on entrepreneurial intentions of business and engineering students in Ethiopia. African Journal of Economic and Management Studies, 3 (2): 258-277

Henry, C., Hill F., and Leitch C. (2005). Entrepreneurship Education and Training: Can Entrepreneurship be Taught? Part I. Education and Training, 47 (2): 98-107

Herrington, Mike, Kew, Jacque, Kew, Penny, (2009). Global Entrepreneurship Monitor, South African Report [Online] Available: http://www.gbs.nct.ac.za/gbswebb/userfiles/gemsouthafrica2000pd (April 15, 2013].

Ismail, M., Khalid, S.A., Othman, M., Jusoff, K., Abdul Rahman, N., Mohammed, K.M., Shekh, R.Z. (2009). Entrepreneurial intention among Malaysian undergraduates. International Journal of Business and Management, 4(10): 54-60.

Inyang B.J., \& Enuoh, R.O (2009). Entrepreneurial Competencies: The Missing Links to Successful Entrepreneurship in Nigeria. International Business Research, 2(2): 62-71.

Klein, P. G., Bullock, J. B. (2006). Can Entrepreneurship be Taught? Journal of Agricultural and Applied Economics , 38 (2), $429-439$.

Kuratko, Donald (2003), Entrepreneurship education: Emerging trends and challenges for the $21^{\text {st }}$ century. [Online] Available: http://www.unm.edu/ asalazar/Kauffman/Entrep_research/e_ed.pdf (May 18, 2014].

Lee, Lena, Wong, Poh (2005), Entrepreneurship Education - A Compendium of Related Issues. [Online] Available: http://papers.ssrn.com/sol3/papers.cfm?abstract_id=856227 (May 10, 2014)

Lee, S. M., Chang, D., Lim, S. B. (2005). Impact of entrepreneurship Education: A Comparative Study of the U. S. and Korea. International Entrepreneurship and Management Journal, (1): 27-43.

Lourenço, F., Jones, O. (2006). Developing entrepreneurship education: comparing traditional and alternative teaching approaches. International Journal of Entrepreneurship Education, 4(1):111-140.

Lourenço, F., Taylor, T.G., Taylor, D.W. (2013).Integrating education for entrepreneurship in multiple faculties in "half-the-time" to enhance graduate entrepreneurship. Journal of Small Business \& Enterprise Development, 20(3): 503 - 525.

Laukkanen, M. (2000). Exploring alternative approaches in high-level entrepreneurship education: Creation micro mechanisms for endogenous regional growth. Journal of Entrepreneurship and Regional Development, 12: 25-47.

Matlay, H. (2006). Researching entrepreneurship and education: Part 2: what is entrepreneurship education and does it matter? Education + Training, 48( 8/9): $704-718$

McClelland DC (1961). The achieving society. Princeton, NJ: Van Nostrand

Mokaya, S.O., Namusonge, M., Sikalieh, D. (2012). The concept of entrepreneurship; in pursuit of a universally acceptable definition. International Journal of Arts and Commerce, 1(6):128-135

Mwasalwiba, E.S. (2010) Entrepreneurship education: a review of its objectives, teaching methods, and impact indicators. Education +Training, 52(1): $20-47$

Phelan, C., Sharpley, R. (2012). Exploring entrepreneurial skills and competencies in farm tourism. Local Economy, 27(2): 103-118.

Raposo, M., do Paço, A. (2011). Entrepreneurship education: Relationship between education and entrepreneurial activity. Psicothema, 23(3): 453-457

Sardeshmukh, S.R., \& Smith-Nelson, R. (2011). Educating for an entrepreneurial career: developing opportunity recognition ability. Australian Journal of Career Development, 20(3): 47-55.

Shepherd, Dean, Douglas, Evan (1997). Is management education developing, or killing, the entrepreneurial spirit? [Online] Available: http://www.researchgate.net/publication/2435925_Is_Management_Education_Developing_or_Killing_the_Entrepreneurial_Spirit (July 3, 2014)

Solomon, G. (2007). An Examination of Entrepreneurship Education in the United States. Journal of Small Business and Enterprise Development, 14 (2), 168-182.

Souitaris, V., Zerbinati, S., Andreas, A. (2007). Do entrepreneurship programmes raise entrepreneurial intention of science and engineering students? The effect of learning, inspiration and resources. Journal of Business Venturing, 22(4): 566-591.

Turton, Natasha, Herrington, Mike, (2013). Global Entrepreneurship Monitor South African 2012 Report. [Online]. Available: http://www.gemconsortium.org/docs/2801/gem-south-africa-2012-report (December 22, 2013) 